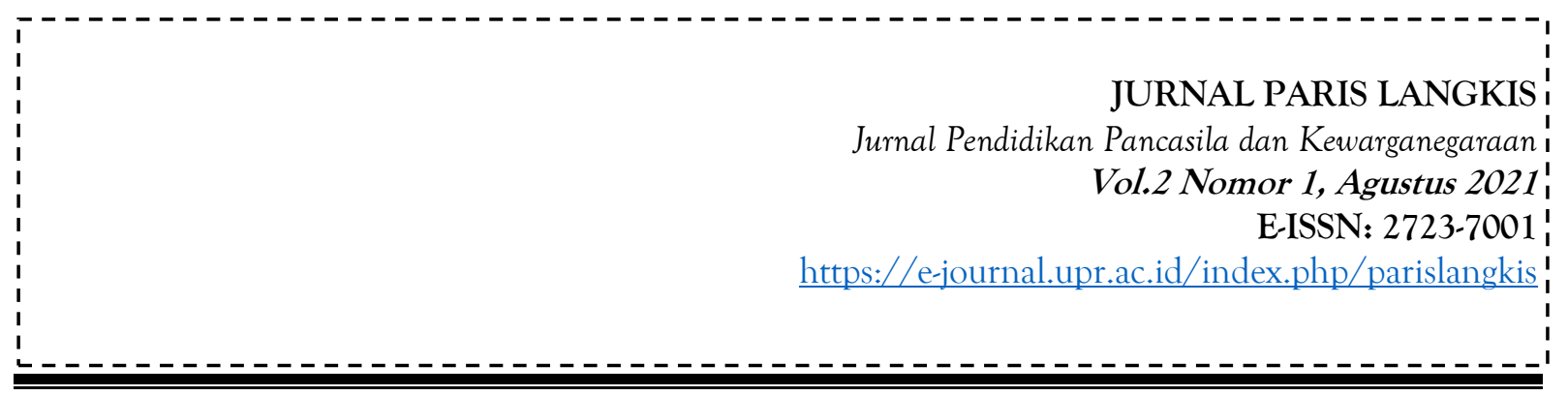

\title{
TEORI HUKUM ISLAM KONTEMPORER : BUNGA BANK (Studi Komparatif Antara Pandangan Ibnu Qayyim dan Muhammad Syahrur)
}

\author{
Hulaiva Pary \\ Mahasiswa Program Pascasarjana Hukum Ekonomi Syariah \\ Universitas Islam Negeri Sunan Gunung Djati Bandung \\ hulaivapary@gmail.com
}

\begin{abstract}
Abstrak
Berbicara mengenai hukum bunga bank, tidak ada habisnya. Apalagi dikalangan hukum islam kontemporer. Banyak dari tokoh-tokoh kontemporer memiliki perbedaan pendapat mengenai hal tersebut. Diantaranya pandangan Ibnu Qayyim dan Muhammad Syahrur). Tujuan penelitian ini untuk membandingkan pandangan tentang bunga bank menurut kedua tokoh kontemporer tersebut (Ibnu Qayyim dan Muhammad Syahrur). Penulis menggunakan pendekatan yuridis normatif dengan memakai penelitian kepustakaan. Adapun jenis penelitian yang digunakan penulis yakni penelitian kualitatif. Hukum bunga bank adalah sesuatu yang cukup Panjang dalam pembahasannya dan cukup ribet dalam perdebatan antara ulama setidaknya dalam permasalahan ini ada beberapa pendapat ulama yang bisa penulis rangkup, bahwa pemikiran Ibnu Qayyim al-Jauziyyah bunga bank tercantum riba Jali, dalam perihal ini diharamkan sebab Riba Jali kemudharatannya lebih besar. Sedangkan bunga bank diperbolehkan ketika pihak peminjam dana adalah pengusaha yang tidak berhak menerima zakat dan sadaqah. Hasil hukum ini tidak lepas dari pemahanan bahwa hukum Islam adalah menghendaki kemaslahatan dan kemudahan bagi umat manusia.
\end{abstract}

Kata Kunci: Teori, Ibnu Qayyim, Muhammad Syahrur, Bunga Bank

\begin{abstract}
Speaking of bank interest laws, there's no end. Especially among contemporary Islamic law. Many of the contemporary figures have disagreements about it. Among them are the views of Ibn Qayyim and Muhammad Shahrur). The purpose of this study was to compare views on bank interest according to the two contemporary figures (IbnQayyim and Muhammad Syahrur). The authors used a normative juridical approach by using literature research. The type of research used by the authors is qualitative research. The law of bank interest is something that is quite long in the discussion and quite complicated in the debate between scholars at least in this matter there are some opinions of scholars who can be the author of the rangkup, that ibn Qayyim al Jauziyyah's view of bank interest including riba Jali, in this case is forbidden because Riba Jali harms greater. While bank interest is allowed when the borrower is an entrepreneur who is not entitled to receive zakat and sadaqah. The result of this law is inseparable from the notion that Islamic law is to require the benefit and ease of mankind.
\end{abstract}

Keywords: Theory, Ibn Qayyim, Muhammad Shahrur, Bank Interest

Paris Langkis

Vol.2 Nomor 1, Agustus 2021 


\section{A. PENDAHULUAN}

Salah satu diantara persoalan yang masih dibicarakan oleh masyarakat kita hingga hari ini adalah persoalan terkait dengan bunga bank. Apakah bunga bank itu tergolong sebagai riba yang diharamkan atau tidak. Kalau kita lihat dalam literatur yang menjelaskan tentang riba baik di kitab-kitab fikih maupun kitab-kitab tafsir maka akan didapat bahwa tidak seorangpun dari ulama yang tidak menghukumi riba itu sebagai sesuatu yang di haramkan dalam arti kata para ulama itu sepakat untuk mengharamkan riba hal itu mereka dasarkan setidaknya kepada beberapa dalil baik dari al-Qur'an ataupun hadis-hadis Nabi, diantara dalil yang mereka jadikan sebagai landasan untuk mengharamkan riba itu adalah surah al-Baqarah ayat 275. Demikian juga salah satu hadis Rasulullah SAW yang diriwayatkan oleh Imam Muslim yang bersumber dari Sayyidina Jabir yakni "Rasulullah SAW mengatakan bahwa Allah SWT melaknat para pemakan riba, kemudian wakilnya, penulisnya, kemudian dua orang saksinya. Kemudian Rasulullah mengatakan "mereka semuanya sama dalam hal dilaknat oleh Allah SWT". Nah itulah beberapa dalil yang menjadi landasan kesepakatan ulama dalam mengharamkan riba, namun hal ini berbeda dengan bunga bank. Para ulama berbeda pendapat dalam hal menghukumi haram atau tidaknya bunga bank. Nah dalam hal ini berdasarkan pembacaan kita terhadap pendapatpendapat para ulama. Maka kita dapat golongkan para ulama terbagi kepada dua golongan secara umum, sebagian dari mereka ada yang memandang bahwa transaksi atau bunga bank itu masuk dalam keumuman istilah riba. Sehingga menurut ulama golongan ini. Bunga bank itu mereka anggap sebagai riba yang diharamkan sebagaimana yang dikandung oleh semangat ayat-ayat yang sudah disebutkan dalam ayat tadi. Diantara para ulama besar dunia yang sependapat dengan pendapat ini adalah Syekh Mutawalli Sya'rawi, Syekh Abu Zahra san dan Syekh Muhammad alGhazali. Mereka sepakat kemudian menggolongkan bunga bank itu masuk ke dalam riba yang diharamkan karena mereka melihat disana adanya kelebihan yang muncul dari transaksi dari sesuatu yang sejenis yaitu uang dengan uang. Kemudian yang kedua, ada ulama yang memandang bahwa bunga bank itu tidak termasuk dalam keumuman ayat yang mengharamkan riba mereka mengatakan bahwa atau mereka berdalil dengan ayat lain yang terdapat dalam surah an-Nisa ayat 29. Nah ulama yang membolehkan mereka menjadikan ayat ini sebagai landasan bahwa riba atau bahwa bunga bank itu bukan termasuk ke dalam riba yang diharamkan. Karena mereka melihat bahwa bunga bank sejatinya adalah sesuatu yang didapatkan oleh nasabah ataupun debitur ataupun kreditur yang dicoba atas dasar suka sama suka dalam artian hal ini tidak ada bentuk penganiayaan ataupun bentuk pemaksaan yang dicoba oleh salah satu dari kedua pihak. Mereka melakukan hal itu secara suka sama suka, dan juga diketahui diawal transaksi. Inilah dalil yang digunakan oleh kelompok yang memandang kalau bunga bank itu tidaklah riba yang diharamkan. Diantara ulama yang berpandangan seperti ini adalah Syekh Ali Jum'ah Mufti Mesir Tahun lalu. Kemudian Syekh Ahmad Thayyib grand Syekh al-Azhar sekarang. Kemudian juga beberapa ulama yang juga berpendapat dengan mereka. Nah menarik kita garis bawahi bahwa salah satu dari ulama yang berpendapat sama dengan kelompok yang membolehkan ini adalah Abdullah Saeed seorang ahli tafsir kontemporer di mana beliau mencoba untuk meneliti ayat-ayat yang berbicara tentang riba pada masa awal-awal Islam beliau berkesimpulan bahwa salah satu penyebab Islam mengharamkan riba pertama kali karena untuk merespon tradisi eksploitasi ekonomi yang dilakukan oleh orang-orang kaya pada saat itu kepada orang-orang yang membutuhkan pinjaman dana, dimana ketika orang yang membutuhkan pinjam itu tidak membayar pinjamnnya sesuai dengan waktu yang sudah mereka tentukan maka orang-orang kaya tersebut dengan seenaknya melipat gandakan nilai pinjamannya menjadi dua, tiga sampai empat kali lipat.

Paris Langkis

Vol.2 Nomor 1, Agustus 2021 
Maka dalam penelitian ini penulis akan memberikan bagaimana komparatif pendapat dari Ibnu Qayyim dan Muhammad Syahrur mengenai hukum bunga bank.

\section{B. HASIL DAN PEMBAHASAN}

\section{Biografi Ibnu Qayyim dan Muhammad Syahrur}

Muhammad bin Abu Bakr ibn Ayyub ibn Sa'ad Ibn Hariz al- Zar' i al- Dimasyqi alHanbali ataupun diketahui dengan istilah Ibnu Qayyim al- Jauziyyah. bapaknya merupakan seseorang pengurus sekolah al- Jauziyyah.

Julukan Ibnu al- Jauzy sesungguhnya tidak pas jika ditumpukan kepada Ibn Qayyim. Istilah ini timbul serta terkenal disebabkan keteledoran para penulis ataupun orang- orang yang idak suka kepada Ibn Qayyim, sebab julukan Ibn al- Jauzy diberikan kepada' Abd al- Rahman ibn' Ali al- Quraisy yang meninggal pada tahun 596 H. Di samping itu terdapat pula sebagian orang yang memiliki julukan Ibn Qayyim al- Jauziyyah. Mereka tidak lain merupakan orang yang mempunyai nasab yang sama dengan bapaknya yang bernama Abu Bakr Ayyub, ialah kerabat kandung Ibn Qayyim( Muhammad ibn Abu Bakr).

Ibnu Qayyim al- Jauziyyah sudah memperlihatkan bakat intelektualitas, pemikiran yang brilian, serta semangat yang besar dalam menuntut ilmu. Dia juga berkembang dalam area yang kesehariannya dipadati dengan kegiatan ilmiah. Bermacam sekolah keagamaan yang spesial mengarahkan ilmu fiqh, hadis, serta kalam banyak tersebar di Mesir serta Siria kala itu. Di antara sekolah- sekolah tersebut yang secara langsung berhubungan dengan kegiatan ilmiah dia merupakan sekolah al- Jauziyyah serta al- Sadriyyah (al-Asy'ari, Oktober 2014, UIN Sunan Kalijaga Yogyakarta. )

Syahrur mempunyai nama lengkap Muhammad Syahrur Ibn Deyb Ibn Seyb Syahrur. Syahrur lahir di Damaskus Syiria pada bertepatan pada 11 April 1938 dari seseorang Bunda yang bernama Siddiqah binti Salih Filyun. Syahrur dikarunai 5( lima) orang anak dari hasil pernikahannya dengan seseorang perempuan yang bernama Azizah (Shah, 2001). Karir intelektual Syahrur diawalinya di lembaga pembelajaran Abdurrahman Al- Kawakibi Damaskus buat pembelajaran dasar serta menengahnya (Muhammad Syahrur, 1990). Syahrur mendapatkan gelar diplomanya pada tahun 1964. Di negara tempat studinya ini, Syahrur berinteraksi dengan pemikrian Marxisme, walaupun Syahrur tidak mengklaim dirinya sebagai penganut Marxisme. Akan tetapi, Pater Clark mengemukakan Syahrur banyak berhutang budi pada wujud Hegel serta Alfred North White head (Clark, 1996). Dalam jangka waktu kurang lebih 4 tahun, (1986-1972) Syahrur selesaikan studi S2 dan S3-nya itu. Pada tahun 1972 kembali ke Damaskus serta jadi dosen senantiasa di situ ((ed.), 2003).

Jika memperhatikan karir akademik dan penjelajahan Syahrur, maka bisa dikatakan bahwa Syahrur memiliki otoritas keilmuan utamanya ada pada bidang teknik. Namun demikian, Syahrur juga tidak menutup diri untuk mempelajari disiplin ilmu lainnya, misalnya bidang filsafat. Pergolakan pemikiran Syahrur telah diawali sejak melanjutkan studinya ke Moskow (Christman, 2004.).

\section{Pemikiran Ibnu Qayyim tentang Bunga Bank}

Riba ialah sesuatu pengambilan bonus dari sesuatu pokok harta dalam secara bathil. Bathil merupakan sesuatu pengambilan bonus dari modal pokok dengan tanpa diiringi terdapatnya upah pengganti ataupun sesuatu kompensasi yang bisa dibenarkan dalam hukum Syariah. Memberikan debitur bunga pokok pinjaman ini setiap kali sudah ada penjadwalan hutang.

Paris Langkis

Vol.2 Nomor 1, Agustus 2021 
Dalam praktek tersebut yang membuat para debitur tak kunjung mampu dalam melunasi hutang-hutang tersebut, yang berarti para debitur mengambil harta saudara-saudaranya dalam kondisi yang keterpurukan. Oleh sebab itu, Allah mengharamkan manusia mempraktekan semacam tersebut, dengan mengutuk pelaku, penulis atau kedua bela saksi-saksinya.

Ibnu Qayyim berpendapat bahwa keharaman merupakan penjelmaan dari sesuatu kaidah ushul yang mempunyai basis dalam (sadd al-Zari'ah). Jadi nanti akan di bolehkan sebab adanya kemaslahatan atau sebab sudah menjadi keseharusan sebagai suatu keperluan masyarakat.

Maka dalam menimbangkan adanya suatu kebutuhan yang tercermin dalam Maqasyid asy-syari'ah, maka berpendapat pada Ibnu Qayyim yang memperbolehkan Riba fadl dengan adanya mekanisme atau mengikuti pandangan dalam masyarakat. Jadi pandangan masyarakat menjadi sebuah acuan yang merujuk pada Maqasyid Syariah. Dalam hal ini juag dapat dikaji dalam sisi kaidah ushul fiqih.

Ibnu Qayyim pula mentolelir terhadap terdapatnya riba jali dalam keadaan yang darurat. Jadi yang diperbolehkan dalam komsumsi santapan serta minuman yang telah diharamkan dalam keadaan yang sama. Salah satu upaya dalam yang dicoba oleh Ibnu Qayyim dalam seluruh aspek pemikiran tentang konsep riba yang ijtihad. Pada pemikiran tersebut merupakan pemikiran yang sangat maju pada zamannya serta selaku wacana dalam perbankan kontemporer, pada sisi lain bila berpegang dalam kaidah yang darurat dalam terdapatnya sebagian keadaan yang telah dikecualikan dalam diperbolehkan yang diharamkan.

Dalam perkembangan dan pandangan Syariah tentang bunga bank hanya terjadi perbedaan dalam penyebutan istilah, namun hal itu dapat berdampak terhadap hasil atau konsekuensi hukum didalamnya, dalam bank Syariah hukum bunga bank tidak ada. Hal demikian lazim disebut dengan bagi hasil dari suatu kesepakatan antara pihak satu dengan yang lainnya, maka teori Ibnu Qoyyim tentang Maqasyid Syariah dan ushul fiqh digunakan dalam memandang sesuatu persoalan tertentu.

Dalam Syariah, modal tersebut harus membentuk suatu keuntungan (profit). Maka dari itu dengan modal tidak diperbolehkan dipinjamkan kepada pihak lainnya jika kecuali dipinjamkan tanpa bunga.

\section{Pemikiran Muhammad Syahrur tentang Bunga Bank}

Polemik mengenai bunga bank saat ini belum pernah sampai pada kesimpulan yang disepakati, dan masing-masing masih kuat memegangi pendapatnya sendiri. Dalam pemikiran Ibnu Qayyim al-Jauziyyah bunga bank tercantum riba Jali, dalam perihal ini diharamkan sebab Riba Jali kemudharatannya lebih besar. Tetapi Riba Jali bisa ditolelir kala terletak dalam keadaan darurat yang mewajibkan buat memanfaatkannya (Rahmat Firdaus, 3, No. 2). Perdebatan itu adalah berawal juga dari perbedaan dalam memberikan makna dari riba sebagaimana disebutkan dalam al-Qur'an.

Bagi Shahrur, berkaitan dengan riba berlaku teori ḥudūd no 6, ialah syarat hukum yang mempunyai batasan atas serta dasar, di mana batasan atasnya bernilai positif(+) serta tidak boleh dilampaui sebaliknya batasan dasar bernilai negatif(-) boleh dilampaui. Batasan atas, yang positif(+) berbentuk riba, sebaliknya batasan dasar yang negatif(-) berbentuk zakat. Batasan dasar dapat dilampaui, ialah dengan membagikan sedekah sunat, di samping membayar zakat yang memanglah hukumnya harus. Di antara kedua batasan ini( positif serta negatif) ada kondisi yang bernilai nol, yang bentuknya berbentuk pemberian kredit dengan tanpa memungut bunga( alqard al-hasan). Sehabis menghimpun serta menganalisis beberapa ayat yang berkenaan dengan riba, Shahrur merumuskan terdapatnya 4 poin berarti menimpa riba yang mesti dicermati, ialah: 
1. Riba berhubungan dengan sedekah, (QS al-Baqarah ayat 276)

2. Riba berhubungan dengan zakat, (QS ar-Rum ayat 39)

2. Riba berhubungan dengan zakat, (QS Ali Imran ayat 130),

4. Adanya kondisi yang bernilai nol. (QS al-Baqarah ayat 279).

Awal, bersumber pada Q. S. al- Taubah: 60, fakir serta miskin tercantum kalangan orang yang berhak menerima zakat. Baginya miskin merupakan orang yang bagi keadaan sosial serta ekonomi yang terdapat, tidak sanggup menutup hutangnya. Terhadap orang dengan keadaan demikian, berlaku ayat:" Allah hendak hapuskan( berkah) riba serta berkembang kembangkan sedekah"( al- Baqarah: 276), di samping pula ayat- ayat lain yang berisi kecaman keras terhadap aplikasi riba( al- Baqarah: 275, 278, serta 279). Oleh sebab itu, harta yang disalurkan kepada mereka pada prinsipnya bukan dalam wujud kredit, namun dalam wujud hibah, serta pahalanya terserah Allah.

Kedua, terhadap orang yang cuma sanggup menutup hutang pokoknya serta tidak sanggup membayar bunga, hingga diberikan pinjaman yang leluasa bunga( al- qard al-hasan). Di mari berlaku ayat 279 al- Baqarah yang melaporkan kalau cuma harta pokok yang boleh dimohon. Kendati demikian, sebab orang ini terkategori orang yang berhak menerima sedekah, hingga hendak lebih utama bila pihak kreditur ingin mem- bebaskan piutangnya.

Ketiga, terhadap para pengusaha yang nota bene bukan berkategori penerima zakat, kredit yang diberikan bisa dipungut bunganya dengan syarat besarnya tidak boleh melampaui batasan yang sudah didetetapkan. Batasan atasnya merupakan jumlah beban bunga yang wajib dibayar sama dengan jumlah hutang pokoknya. Perihal ini bersumber pada ayat:" Hai orangorang mu' min jangan makan riba yang berlipat ganda"( Al- Imran: 130). Atas dasar pemikirannya tentang riba dengan bermacam keadaan objektif yang melingkupinya sebagaimana disebutkan di atas, Shahrur mengajukan 3 prinsip dasar sistem perbankan Islam, ialah:

1. Mereka yang berhak menerima zakat tidak diberikan kredit, melainkan diberi hibah( sedekah)

2. Dalam keadaan tertentu dibuka mungkin buat berikan kredit yang leluasa bunga, ialah untuk mereka yang pantas diberi sedekah.

3. Dalam bank Islam tidak boleh terdapat kredit yang tempo pembayarannya tidak dibatasi sampai beban bunga yang wajib dibayar lebih besar daripada hutang pokoknya. Bila perihal ini terjalin, hingga pihak debitur berhak menolak buat membayar bunga yang melebihi batasan tersebut.

Batasan paling tinggi ditafsirkan selaku bunga bank, lagi batasan terendah selaku pembayaran zakat. Batasan- batasan ini terletak dalam bundaran posisi positif serta negatif, hingga terdapat suatu tingkatan yang terletak pas di antara lain yang nilainya sama dengan nol. Contoh dari tingkatan tengah ini merupakan hutang leluasa bunga.

Dengan demikian, bagi Shahrur, bunga merupakan riba, tetapi dia boleh dipungut asal mencermati keadaan objektif pihak debitur. Debitur dari golongan anggota warga yang tercantum dalam jenis mustahiq zakat serta sedekah, tercantum orang yang cuma sanggup membayar hutang pokok, tidak boleh dipungut riba, apalagi sebagian dari mereka sebaiknya tidak diberi kredit, melainkan hibah. Tidak hanya dari golongan mereka, riba boleh dipungut, namun tidak boleh melebihi batasan atas yang sudah didetetapkan.

\section{KESIMPULAN}

Dalam pemikiran Ibnu Qayyim al-Jauziyyah bunga bank tercantum riba Jali, dalam perihal ini diharamkan sebab Riba Jali kemudharatannya lebih besar. Tetapi Riba Jali bisa 
ditolelir kala terletak dalam keadaan darurat yang mewajibkan buat memanfaatkannya. Sedangakan menurut Muhammad Syahrur permasalahan riba yang masih menjadi polemik dalam penerapannya di dunia modern dijawab oleh Shahrur, bahwa riba yang dilarang hanyalah kalau ada unsur kezaliman terhadap pihak lain, dan bunga bank diperbolehkan ketika pihak peminjam dana adalah pengusaha yang tidak berhak menerima zakat dan sadaqah. Hasil hukum ini tidak lepas dari pemahanan bahwa hukum Islam adalah menghendaki kemaslahatan dan kemudahan bagi umat manusia.

\section{DAFTAR PUSTAKA}

al-Asy'ari, M. Khoirul Hadi. "Riba Dan Bunga Bank Dalam Pandangan Ibnu Qayyim", Jurnal Syari'ah Vol. II, No. II, Oktober 2014, UIN Sunan Kalijaga Yogyakarta. Diakses pada tanggal 08 Juli 2021.

Clark, Eter. 1996. "The Sahrur Phenomenon: a Liberal Islamic Voice From Syiria" dalam Islam and Christian Muslim Relations, Vol. 7, No. 3.

Christman, Andreas. dalam Die Wel des Islams, terj. Sahiron Syamsudin, 2004. Meteodologi Fiqih Islam Kontemporer. Yogyakarta: eLSAQ Press.

Firdaus, Rahmat. "Perbedaan Pandangan Fuqaha Ihwal Bunga Bank dan Riba," Ekonomika Syariah: Journal of Economic Studies 3, No. 2.

Rumsida, Sya'baniyah. "Bunga Bank Perspektif Fazlurrahman Dan Wahbah Az-Zuhaili”. Artikel Publikasi, Universitas Muhammadiyah Surakarta. Di akses pada tanggal 07 Juli 2021

Shah, M. Abul Abied. 2001. Islam Garda Depan Mozaik Pemikiran Islam Timur Tengah. Bandung: Mizan.

Syahrur, Muhammad. 1990. "Al-Kitab wa al-Qur'an: Qira'ah Mu'asirah.Damaskus: al-Ahali li athThiba'ah li An-Nasyr wa at-tauzi,.

Syamsudin Sahiron. 2003. "Hermeneutika Al-Qur'an Mazhab Yogya". Yogyakarta: Islamika.

Sahrin, Abu. "Metode Hermeneutika Alquran: Analisis Teori Batas Menurut Muham-mad Shahrur," Ibn Abbas: Jurnal Ilmu Alquran dan Tafsir 1 No. 2

Wartoyo," Riba Dan Bunga Bank (Studi Komparatif Pemikiran Abdullah Saeed dan Yusuf Qardhawi)", Artikel Syariah Fakultas Syariah dan Ekonomi Islam IAIN Syekh Nurjati Cirebon. Diakses pada tanggal 08 Juli 2021. 